\title{
Correction: Revising the eclipse prediction scheme in the Antikythera mechanism
}

Tony Freeth ${ }^{1}$

Correction to: Palgrave Communications https://doi.org/10.1057/s41599-018-0210-9, Published online 22 January 2019

In Fig. 7c, the character in the second row under the numeral 213 in the L.29 group should have been the symbol " 2 ", not the Greek Letter Psi. This has now been corrected in the article.

Published online: 05 March 2019

\begin{abstract}
(c) (i) Open Access This article is licensed under a Creative Commons Attribution 4.0 International License, which permits use, sharing, adaptation, distribution and reproduction in any medium or format, as long as you give appropriate credit to the original author(s) and the source, provide a link to the Creative Commons license, and indicate if changes were made. The images or other third party material in this article are included in the article's Creative Commons license, unless indicated otherwise in a credit line to the material. If material is not included in the article's Creative Commons license and your intended use is not permitted by statutory regulation or exceeds the permitted use, you will need to obtain permission directly from the copyright holder. To view a copy of this license, visit http://creativecommons.org/licenses/by/4.0/.
\end{abstract}

(C) The Author(s) 2019 